\title{
Purification and Partial Characterization of the Serologically Active Substance from Absidia cylindrospora
}

\author{
By OSAMU HAYASHI, HARUKI YAMADA, TOSHIRO YADOMAE \\ AND TOSHIO MIYAZAKI \\ Department of Microbial Chemistry, Tokyo College of Pharmacy, \\ Hachioji, Tokyo 192-03, Japan
}

(Received 4 October 1977; revised 27 January 1978)

\begin{abstract}
Affinity chromatography with a concanavalin A-Sepharose column was successfully used to separate the serologically active substance of Absidia cylindrospora from the supernatant of disrupted mycelium fluid, the phenol extract of intact washed mycelium and the culture filtrate. The active substance, a fucomannan-peptide, was isolated homogeneously by means of zone electrophoresis using Pevikon. It was composed of fucose and mannose $(94.6 \%, \mathrm{w} / \mathrm{w})$ in the ratio $1: 2.2$ and a small amount of protein $(1.8 \%, \mathrm{w} / \mathrm{w})$. It may be bound loosely on the surface of the mycelium.
\end{abstract}

\section{INTRODUCTION}

Numerous fungal polysaccharides and glycoproteins were reviewed by Gorin \& Spencer (1968), and classification of fungal polysaccharides was described by Bartnicki-Garcia (1968). A number of investigators have studied the chemical and immunological properties of mannans and mannose-containing polysaccharides such as galactomannans and rhamnomannan. These fungal polysaccharides were the major cell wall antigens. The cell wall polysaccharides of Mucor rouxii have been studied chemically by Bartnicki-Garcia and co-workers (Bartnicki-Garcia \& Reyes, 1968; Bartnicki-Garcia \& Lindberg, 1972). Miyazaki \& Irino $(1970,1972)$ have reported the isolation and characterization of acidic polysaccharides from the cell walls and culture filtrates of Absidia cylindrospora, Mucor mucedo and Rhizopus nigricans, which are all members of the Mucorales. Recently, a serologically active substance(s) of $A$. cylindrospora was found in the supernatant obtained by centrifugation of disrupted cells (Miyazaki et al., 1977). The present paper describes the chemical properties and the morphological localization of this serologically active substance from $A$. cylindrospora.

\section{METHODS}

Analytical methods. Total carbohydrate was determined by the phenol-sulphuric acid method (Dubois et al., 1956), protein by the method of Lowry et al. (1951) using bovine serum albumin as a standard, and phosphate by the method of Fiske \& Subbarow (1925). Hexosamine was determined after hydrolysis with $4 \mathrm{M}-\mathrm{HCl}$ for $10 \mathrm{~h}$ at $100^{\circ} \mathrm{C}$ by the methods of Blix (1948) and Gardell (1953) using glucosamine hydrochloride as a standard.

The component sugars were determined qualitatively by paper chromatography. Each sample was hydrolysed with $0.5 \mathrm{M}^{-\mathrm{H}_{2}} \mathrm{SO}_{4}$ at $100{ }^{\circ} \mathrm{C}$ for $8 \mathrm{~h}$. The hydrolysate was neutralized with $\mathrm{BaCO}_{3}$, filtered and concentrated to a syrup. A portion of the concentrate was examined by the ascending method on a Toyo Roshi no. 50 filter paper using the solvent system ethyl acetate/pyridine/acetic acid/water (5:5:1:3, by vol.). Sugars on the chromatogram were detected by the following reagents: alkaline silver nitrate (Trevelyan, Procter \& Harrison, 1950), p-anisidine hydrochloride (Hough, Jones \& Wadman, 1950) and ninhydrin (Partridge, 1948). 
The molar ratio of neutral sugars in each sample was dutermined by gas-liquid chromatography (g.l.c.) of the alditol acetate derivatives of the acid hydrolysate (Miyazaki et al., 1976). A Shimadzu GC-6A chromatograph (Shimadzu, Tokyo, Japan) equipped with a glass column $(0.3 \times 200 \mathrm{~cm})$ containing $5 \%$ ECNSS-M on chromosorb-W (AW-DMCS, 60 to 80 mesh) was used in the g.l.c. analysis. The column temperature was $190^{\circ} \mathrm{C}$.

Paper electrophoresis using $0.026 \mathrm{M}$-sodium borate was performed on a Toyo Roshi no. 50 filter paper at a constant current of $1.5 \mathrm{~mA} \mathrm{~cm}^{-1}$ for $3 \mathrm{~h}$. After drying the paper, polysaccharides were detected by periodateSchiff reagent (Köiw \& Grönwall, 1952).

Preparation of the purified cell wall and extracellular material. The purified cell wall of $A$. cylindrospora IFo 4000, designated ACW, was obtained by disruption in a French press, followed by washing with sodium dodecyl sulphate (SDS) and distilled water, and centrifugation as described previously (Miyazaki et al., 1977).

The culture filtrate was dialysed in a Visking tube against distilled water for $3 \mathrm{~d}$ at $4{ }^{\circ} \mathrm{C}$. The non-dialysable fraction was concentrated to about $500 \mathrm{ml}$ and then lyophilized. The resulting powder was designated ACE.

Preparation of antisera. ACW and ACE were suspended in saline to give $20 \mathrm{mg} \mathrm{ml}^{-1}$ and $10 \mathrm{mg} \mathrm{ml}^{-1}$, respectively. The suspension of ACW was homogenized in a Teflon homogenizer. Emulsions of ACW and ACE were prepared by adding an equal volume of Freund's complete adjuvant (Difco). Male New Zealand white rabbits, each weighing 2.5 to $3.0 \mathrm{~kg}$, were immunized with $0.5 \mathrm{ml}$ of the emulsions by intracutaneous injection once a week for 3 or 6 weeks. One or two weeks after the last injection, the rabbits were bled and the separated sera were stored frozen. These antisera were designated anti-ACW serum and anti-ACE serum. Further antiserum, designated anti-ACWC serum, was prepared by immunizing a rabbit with $0.5 \mathrm{ml}$ of a homogenate of whole cells in saline $\left(100 \mathrm{mg}\right.$ wet wt $\left.\mathrm{ml}^{-1}\right)$ once a week for 7 weeks; this antiserum was also stored frozen.

Immunochemical methods. Immunodiffusion analysis with $1 \%(\mathrm{w} / \mathrm{v})$ Golden Agar (Kyokuto Seiyaku, Japan) in $0.15 \mathrm{M}$-phosphate-buffered saline ( $\mathrm{pH} 7.0$ ) was done according to the method of Ouchterlony (1949).

The quantitative precipitin test was carried out as follows. Undiluted rabbit antiserum $(0 \cdot 2 \mathrm{ml})$ was mixed with $0.1 \mathrm{ml}$ of serial dilutions of antigen (ACI-B) in saline. The mixtures were incubated at $37^{\circ} \mathrm{C} \mathrm{for} 1 \mathrm{~h}$, stored at $4{ }^{\circ} \mathrm{C}$ for $90 \mathrm{~h}$ with occasional shaking and then centrifuged. The precipitates were washed twice with $6 \mathrm{ml}$ cold saline and the protein in the precipitated complex was determined by the method of Lowry et al. (1951).

Immunoelectrophoresis was carried out with $1 \%(\mathrm{w} / \mathrm{v})$ agar made up in $0.087 \mathrm{M}$-veronal buffer (pH 8.6). Anti-ACE serum was added after electrophoresis at a constant current of $30 \mathrm{~mA}$ for $1 \mathrm{~h}$ and diffusion was allowed to take place at $22^{\circ} \mathrm{C}$ for 1 to $5 \mathrm{~d}$.

Separation of the serologically active fractions. The supernatant fluid of the cell homogenate was separated from the pellet of the cell wall fraction by centrifugation as described previously (Miyazaki et al., 1977). The residual cell wall fraction was resuspended in cold saline, the suspension was homogenized with a Teflon homogenizer, and the supernatant was separated by centrifugation. The combined supernatants were dialysed against distilled water for $3 \mathrm{~d}$ at $4{ }^{\circ} \mathrm{C}$ and lyophilized. The resulting powder was resuspended in saline and the solution was centrifuged at $100000 \mathrm{~g}$ for $60 \mathrm{~min}$ at $4{ }^{\circ} \mathrm{C}$. After dialysis, the soluble supernatant was lyophilized and designated ACI.

Washed mycelium (110 g wet wt) was extracted with $500 \mathrm{ml}$ of $45 \%$ (v/v) phenol at 65 to $75{ }^{\circ} \mathrm{C}$ for $1 \mathrm{~h}$ by the method of Westphal \& Jahn (1965). After cooling in an ice bath, the phenol extract was filtered and centrifuged for $30 \mathrm{~min}$ at $15000 \mathrm{rev} \cdot \mathrm{min}^{-1}$ at $5^{\circ} \mathrm{C}$. The aqueous layer of the supernatant was lyophilized after extensive dialysis against running tap water and distilled water. The resulting white powder was designated $\mathrm{PhW}$. The yield was $210 \mathrm{mg}$.

Portions $(100 \mathrm{mg})$ of each of the fractions ACI, PhW and ACE were dissolved in 0.15 M-phosphate buffer (pH 7.0) and the solutions were placed in a boiling water bath for $15 \mathrm{~min}$. After cooling, each solution was applied to a column $(1.5 \times 45 \mathrm{~cm})$ of concanavalin A (Con A)-Sepharose 4B and eluted with $0 \cdot 15 \mathrm{M}$-phosphate buffer ( $\mathrm{pH} \mathrm{7.0)}$ ), to give fractions ACI-A, PhW-A and ACE-A, and then with 0.5 M- $\alpha$-methyl-Dmannoside in the same buffer, to give fractions ACI-B, PhW-B and ACE-B.

Periodate oxidation and pronase/trypsin digestion of $A C I-B$. ACI-B $(15 \mathrm{mg})$ was oxidized with $0.015 \mathrm{M}-$ $\mathrm{NaIO}_{4}$ at $4{ }^{\circ} \mathrm{C}$ in the dark. After $24 \mathrm{~h}$, the reaction was stopped by adding $1 \mathrm{ml}$ ethylene glycol. After dialysis for $3 \mathrm{~d}$ followed by lyophilization, the oxidized ACI-B was obtained in a yield of $10.9 \mathrm{mg}$. The oxidized ACI-B was then reduced with $\mathrm{NaBH}_{4}$ overnight at room temperature. The reaction mixture was acidified with acetic acid, dialysed for $2 \mathrm{~d}$ and lyophilized.

ACI-B $(10 \mathrm{mg})$ was dissolved in $5 \mathrm{ml} 0.05 \mathrm{M}$-Tris/ $\mathrm{HCl}$ buffer (pH 7.9) containing $0.01 \mathrm{M}-\mathrm{CaCl}_{2}$ and $2 \mathrm{mg}$ pronase (Kaken Kagaku, Japan). The mixture was passed through a Millipore filter $(0.45 \mu \mathrm{m}$ pore size) and then incubated at $37^{\circ} \mathrm{C}$ for $48 \mathrm{~h}$. After heating in a boiling water bath for $10 \mathrm{~min}$, the mixture was dialysed against $0.05 \mathrm{M}$-Tris/ $\mathrm{HCl}$ buffer ( $\mathrm{pH} \mathrm{7.5)}$ for $2 \mathrm{~d}$. Trypsin ( $2 \mathrm{mg}$; Boehringer) was added to the 
non-dialysable solution. The mixture was passed through a Millipore filter and incubated at $37^{\circ} \mathrm{C}$ for $24 \mathrm{~h}$. After heating for $10 \mathrm{~min}$ the reaction mixture was dialysed against distilled water and then the non-dialysable solution was lyophilized.

Purification of $A C I-B$ by zone electrophoresis. ACI-B $(100 \mathrm{mg})$ was purified by zone electrophoresis using Pevikon C-870 (polyvinyl resin, M \& S Instruments, Japan) as a supporting medium $(1.5 \times 7.0 \times 40 \mathrm{~cm}$ ) equilibrated with $0.026 \mathrm{M}$-sodium borate. After migration at a constant current of $40 \mathrm{~mA}$ for $15 \mathrm{~h}$, the Pevikon block was cut into 40 segments and each segment was quantitatively extracted with $5 \mathrm{ml} 0.026 \mathrm{M}-$ sodium borate solution. The sugar content of each extract was determined using the anthrone-- $\mathrm{H}_{2} \mathrm{SO}_{4}$ reagent (Morris, 1948).

\section{RESULTS}

\section{Chemical analysis of the purified cell wall}

Examination by light and electron microscopy indicated that the purified cell wall of A. cylindrospora, prepared as described in Methods, was free from cytoplasmic material. The yield of purified wall was $1.5 \mathrm{~g}(1 \text { culture })^{-1}$. The purified walls contained $23.9 \%(\mathrm{w} / \mathrm{w})$ neutral sugar comprising fucose, mannose and galactose in the molar ratio 10:1:2. They also contained hexosamine $(31.4 \%, w / w)$, protein $(3.2 \%, w / w)$, extractable lipid $(1.7 \%$, $\mathrm{w} / \mathrm{w})$ and small amounts of glucuronic acid.

\section{Separation of the serologically active fractions}

By means of affinity chromatography on Con A-Sepharose, the serologically active fractions, ACI-B, PhW-B and ACE-B, were obtained as adsorbed fractions. ACI-A, $\mathrm{PhW}-\mathrm{A}$ and ACE-A were obtained as unadsorbed fractions. These fractions were lyophilized after dialysis against distilled water for $3 \mathrm{~d}$. A representative elution pattern of ACI is shown in Fig. 1. The yields of the various fractions are given in Table 1. Fractions ACI-B, PhW-B and ACE-B contained relatively large amounts of carbohydrate and small amounts of protein (Table 2). Paper electrophoresis of ACI-B and ACE-B revealed two components in each, but $\mathrm{PhW}-\mathrm{B}$ behaved as a single compound with the same mobility as the main component of fractions ACI-B and ACE-B.

Table 1. Recovery of the serologically active fractions

\begin{tabular}{|c|c|c|c|c|}
\hline & $\operatorname{Rec}$ & $\%(v$ & of starting & terial] \\
\hline & & & & \\
\hline & $A_{1}$ & $\mathrm{~A}_{2}$ & Fraction B & Total \\
\hline $\mathrm{ACI}$ & $7 \cdot 0$ & $8 \cdot 0$ & $76 \cdot 1$ & $91 \cdot 1$ \\
\hline $\mathrm{ACE}$ & & & $44 \cdot 7$ & $73 \cdot 6$ \\
\hline $\mathrm{PhW}$ & & & $26 \cdot 4$ & $39.8 *$ \\
\hline
\end{tabular}

Table 2. Chemical analysis of $A C I-B, P h W-B$ and $A C E-B$

$\begin{array}{lccccc} & \begin{array}{c}\text { Neutral } \\ \text { sugar } \\ \text { content* } \\ (\%, \mathrm{w} / \mathrm{w})\end{array} & \begin{array}{c}\text { Molar ratio } \\ \text { of fucose } \\ \text { and mannose } \dagger\end{array} & \begin{array}{c}\text { Protein } \\ \text { content } \\ (\%, \mathrm{w} / \mathrm{w})\end{array} & \begin{array}{c}\text { Phos- } \\ \text { phorus } \\ \text { content } \\ (\%, \mathrm{w} / \mathrm{w})\end{array} & \begin{array}{c}\text { Total } \\ (\%, \mathrm{w} / \mathrm{w})\end{array} \\ \text { ACI-B } & 63.0 & 1: 2 \cdot 51 & 22 \cdot 7 & 2 \cdot 3 & 88.0 \\ \text { PhW-B } & 80.7 & 1: 2 \cdot 31 & 8.9 & 0.6 & 90 \cdot 2 \\ \text { ACE-B } & 55.6 & 1: 2 \cdot 49 & 7 \cdot 7 & 5 \cdot 0 & 68 \cdot 3\end{array}$

* Standards used for the determination of neutral sugar content were prepared on the basis of the molar ratio of fucose and mannose (calculated from the results of g.l.c.) in each sample.

$\dagger$ Traces of galactose, glucosamine, galactosamine and glucuronic acid were also detected in all fractions. 


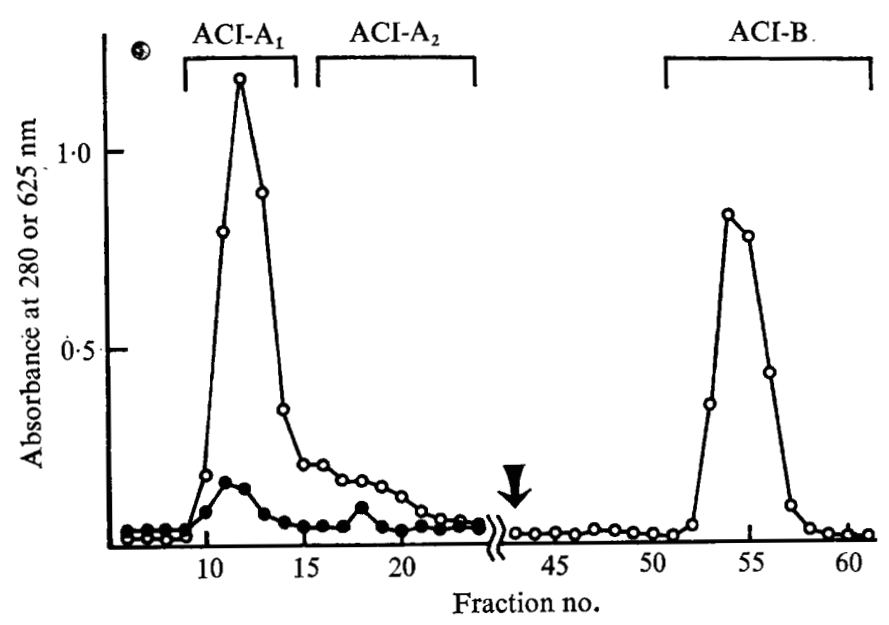

Fig. 1. A representative elution pattern of ACI on a column of Con A-Sepharose: $5 \mathrm{ml}$ fractions were collected, and elution with $0.5 \mathrm{M}-\alpha$-methyl-D-mannoside commenced at the arrow. $O, A_{280}$; , $A_{625}$. The elution patterns of $\mathrm{PhW}$ and $\mathrm{ACE}$ were similar to that of ACI.

\section{Serological reactivities of anti- $A C W C$, anti-ACW and anti-ACE sera with $A C I-B$ and other fractions}

The maximum dilutions of anti-ACWC, anti-ACW and anti-ACE sera that formed precipitates with ACI-B (312.5 $\mu \mathrm{g} \mathrm{ml}^{-1}$ in saline) in a fine glass tube were $1: 1,1: 1$ and $1: 8$, respectively. Quantitative precipitin curves of these three antisera with ACI-B showed that precipitation of anti-ACE serum with ACI-B occurred to a larger extent than did precipitation of anti-ACWC and anti-ACW sera with ACI-B (about one-eighth of the reactivity of anti-ACE serum). The immunodiffusion pattern of these antisera with ACI-B showed a fused single precipitin line (Fig. 2). These antisera also reacted with $\mathrm{PhW}-\mathrm{B}$ and ACE-B to give a precipitin band in a fine glass tube. Sera absorbed with ACI-B did not react with ACI-B, PhW-B or ACE-B.

\section{Immunochemical properties of $A C I-B, P h W-B$ and $A C E-B$}

ACI-B, PhW-B and ACE-B, which had affinity for Con A, reacted strongly with antiACE serum. Immunodiffusion of ACI-B, PhW-B and ACE-B with the antiserum gave distinct precipitin lines which fused with each other (Fig. 3). The results of immunoelectrophoresis showed that these fractions gave precipitin arcs with anti-ACE serum which were similar to each other in their mobilities (Fig. 4).

To elucidate whether the serologically reactive site is a carbohydrate or a peptide moiety, ACI-B was subjected to periodate oxidation and digestion with proteolytic enzymes. Portions $(25 \mu \mathrm{g})$ of periodate-oxidized ACI-B and pronase/trypsin-digested ACI-B were examined by immunodiffusion with anti-ACE serum $(10 \mu \mathrm{l})$. Periodate-oxidized ACI-B $\left(3 \mathrm{mg} \mathrm{ml}^{-1}\right)$ and its serial dilutions in saline were also used for the precipitin reaction in a fine glass tube. Periodate-oxidized ACI-B did not react with anti-ACE serum, but digestion of ACI-B with pronase and trypsin did not affect its serological reactivity.

ACI-A and ACE-A also reacted with anti-ACE serum, but the precipitin lines after immunodiffusion were different from those of ACI-B, PhW-B and ACE-B. However, the reaction only occurred to a slight degree.

\section{Further purification of the fucomannan-peptide fraction}

Zone electrophoresis of ACI-B gave two peaks, ACI-B-I and ACI-B-III (Fig. 5). The homogeneity of the major peak, ACI-B-III, was confirmed by paper electrophoresis and by 


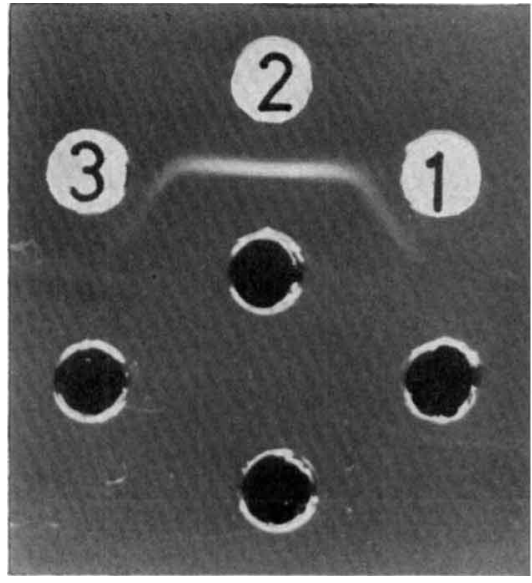

Fig. 2

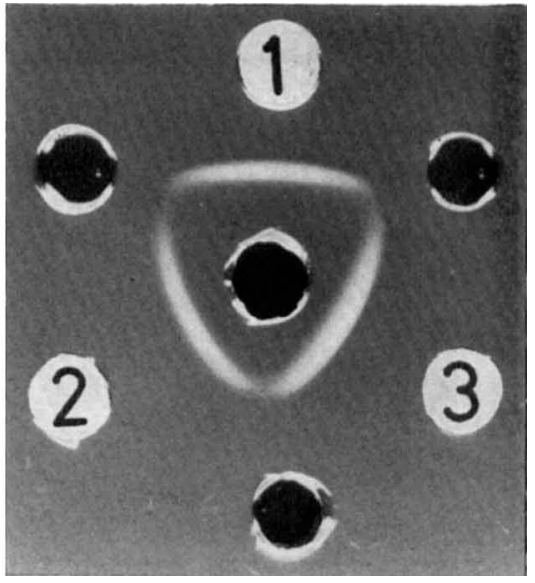

Fig. 3

Fig. 2. Immunodiffusion pattern of anti-ACWC serum (well 1, $10 \mu 1$ ), anti-ACE serum (well 2, $10 \mu \mathrm{l}$ ) and anti-ACW serum (well 3,10 $\mu \mathrm{I}$ ) with ACI-B (centre well, 12.5 $\mu \mathrm{g}$ ).

Fig. 3. Immunodiffusion pattern of the serologically active fractions ACI-B (well 1, 12.5 $\mu \mathrm{g}$ ), PhW-B (well 2, 12.5 $\mu \mathrm{g}$ ) and ACE-B (well 3, 12.5 $\mu \mathrm{g}$ ) with anti-ACE serum (centre well, $10 \mu \mathrm{l}$ ).

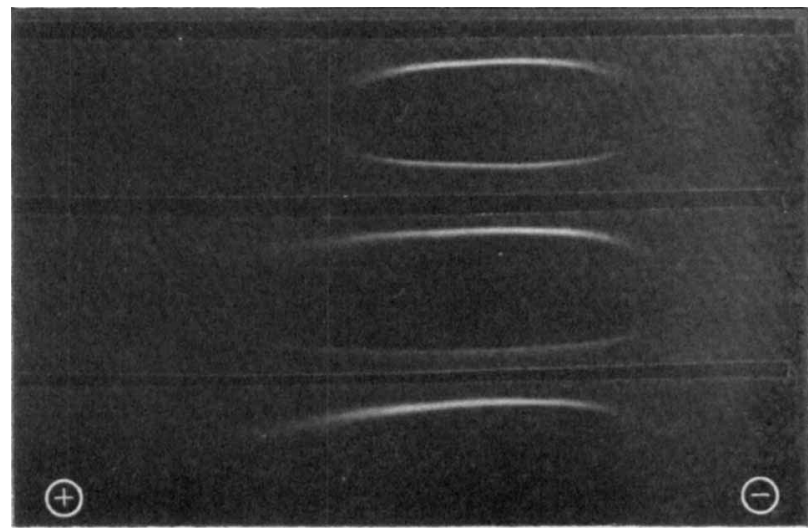

Fig. 4. Immunoelectrophoresis of ACI-B (upper well, $30 \mu \mathrm{g}$ ), PhW-B (centre well, $30 \mu \mathrm{g}$ ) and ACE-B (lower well, $30 \mu \mathrm{g}$ ), with anti-ACE serum $(30 \mu \mathrm{l})$ in the troughs.

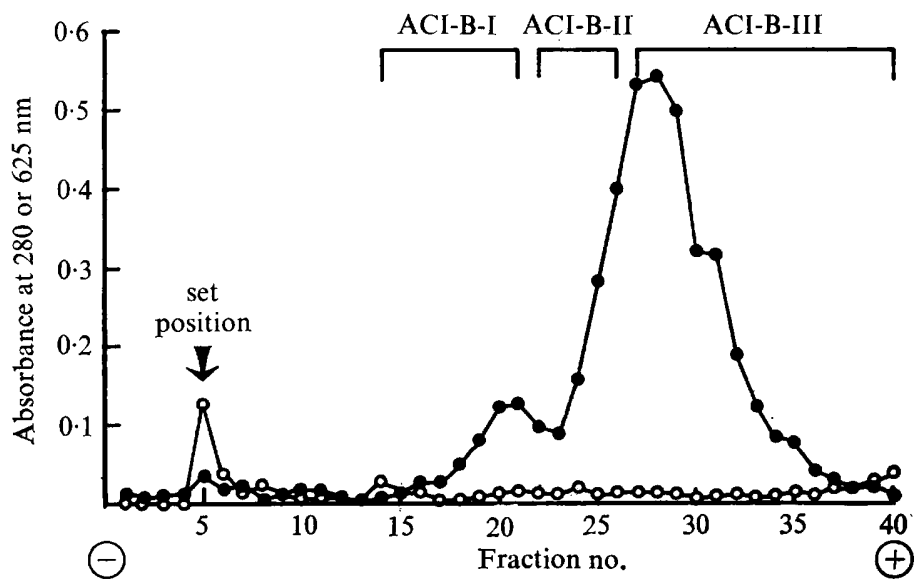

Fig. 5. Zone electrophoresis of ACI-B: $\bigcirc, A_{280}$; , $A_{625}$. 

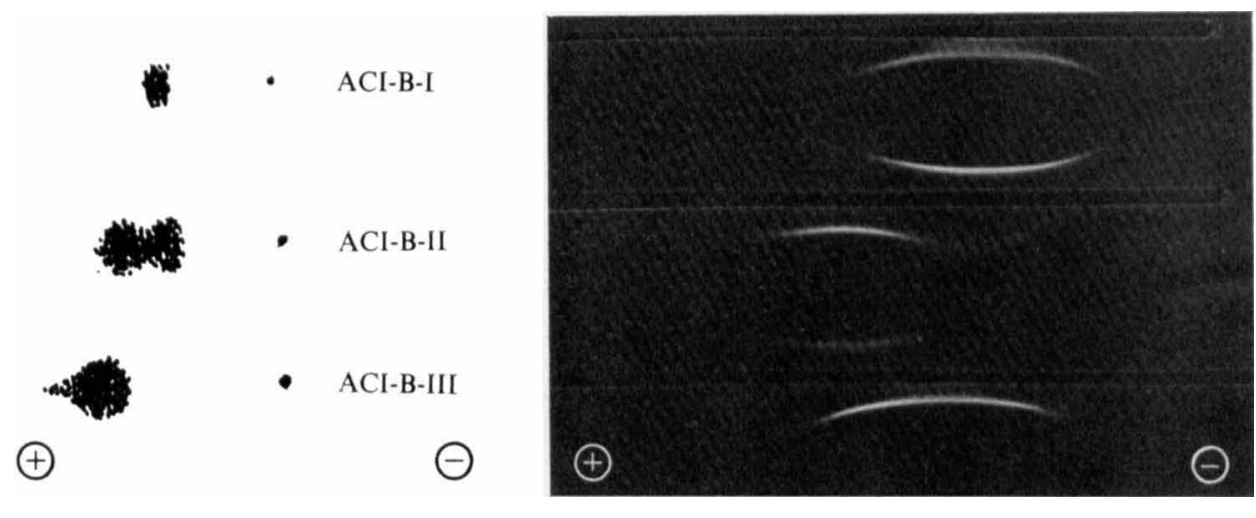

Fig. 6. (Left) Paper electrophoresis of ACI-B-I, ACI-B-II and ACI-B-III in 0.026 M-borate buffer at a constant current of $1.5 \mathrm{~mA} \mathrm{~cm} \mathrm{~cm}^{-1}$ for $3 \mathrm{~h}$. Polysaccharides were detected by the periodate-Schiff reagent. (Right) Immunoelectrophoresis of ACI-B-I (upper well, $75 \mu \mathrm{g}$ ), ACI-B-III (centre well, $95 \mu \mathrm{g}$ ) and ACI-B (lower well, $105 \mu \mathrm{g}$ ), with anti-ACE serum $(30 \mu \mathrm{l})$ in the troughs.

immunoelectrophoresis against anti-ACE serum using $0.087 \mathrm{M}$-veronal buffer ( $\mathrm{pH} 8.6$ ) (Fig. 6). ACI-B-III contained carbohydrate $[94.6 \%(\mathrm{w} / \mathrm{w})$ as mannose], which was composed of fucose and mannose (in the molar ratio $1: 2 \cdot 2$ ), and a small amount of protein $(1.8 \%, w / w)$. The minor peak, ACI-B-I, was too small to allow chemical analysis. In immunoelectrophoresis, the precipitin arc of ACI-B-I with anti-ACE serum was different from that of ACI-B-III in its mobility but the precipitin lines of these in the immunodiffusion pattern fused completely.

\section{DISCUSSION}

Miyazaki et al. (1977) showed that the serologically active substance of $A$. cylindrospora was found mainly in the supernatant obtained from the disrupted cells by centrifugation and that it was obtained only in a low yield from the purified cell wall. The antibody titre of anti-ACE serum was higher than that of anti-ACW serum. As shown in Table 2 and Figs 3 and 4, it appears that fractions ACI-B, PhW-B and ACE-B contain a common active substance. These observations suggest that the serologically active substance of $A$. cylindrospora may be loosely bound on the surface of the mycelium and easily released from the surface. This active substance was isolated homogeneously as the major peak, ACI-B-III, by means of zone electrophoresis on Pevikon. It was a fucomannan-peptide composed of fucose and mannose in a $1: 2.2$ molar ratio and a very small amount of protein. The serologically active site of this polymer may be a carbohydrate rather than a peptide moiety since periodate oxidation of ACI-B destroyed its reactivity with anti-ACE serum whereas pronase/trypsin digestion did not.

Miyazaki \& Irino (1970) isolated an acidic polysaccharide composed of L-fucose, D-galactose and D-glucuronic acid from an alkali extract of the cell wall of $A$. cylindrospora. The alkali extract had no serological reactivity with anti-wall serum in spite of the presence of the fucose-containing polysaccharide (Miyazaki et al., 1977). Therefore, it appears that the fucomannan-peptide is different from the polysaccharides in the cell wall such as mucoric acid and mucoran (Bartnicki-Garcia \& Reyes, 1968) and the acidic polysaccharide.

Mannans and mannose-containing heteropolysaccharides in yeast and other fungi are well known as fungal antigens. Galactomannans have been obtained from many species of fungi such as Histoplasma (Azuma et al., 1974), Trichophyton, Cladosporium werneckii, Penicillium and Aspergillus (Gander, 1974). Furthermore, a peptido-rhamnomannan has been isolated from Sporothrix schenckii and studied immunochemically (Lloyd \& Travassos, 1975). Fucose is an uncommon constituent of fungal polysaccharides except in the Mucorales and Basidiomycetes (Bartnicki-Garcia, 1968; Gorin \& Spencer, 1968). In the Mucorales, 
it remains to be seen whether the fucomannan-peptide is an antigenic substance common to many species or specific to $A$. cylindrospora. Studies on the cross-reactivity of the anti-ACE serum with other Mucorales or fungi are now in progress.

We thank Messrs S. Shinoda, T. Ogawa and N. Okumura for technical assistance.

\section{REFERENCES}

Azuma, I., Kanetsuna, F., Tanaka, Y., YamamURA, Y. \& CaRbonell, L. M. (1974). Chemical and immunological properties of galactomannans obtained from Histoplasma duboisii, Paracoccidioides brasiliensis and Blastomyces dermatitidis. Mycopathologia et mycologia applicata 54, 111125.

Bartnicki-Garcia, S. (1968). Cell wall chemistry, morphogenesis and taxonomy of fungi. Annual Review of Microbiology 22, 87-108.

BARTNICKI-GARCIA, S. \& LiNDBERG, B. (1972). Partial characterization of mucoran: the glucuronomannan component. Carbohydrate Research $23,75-85$.

Bartnicki-Garcia, S. \& Reyes, E. (1968). Polyuronides in the cell walls of Mucor rouxii. Biochimica et biophysica acta 170, 54-62.

BuIX, G. (1948). The determination of hexosamine according to Elson and Morgan. Acta chemica scandinavica 2, 467-473.

Dubois, M., Gilles, K. A., Hamilton, J. K., Rebers, P. A. \& Sмith, F. (1956). Colorimetric method for determination of sugars and related substances. Analytical Chemistry 28, 350-356.

Fiske, C. H. \& Subbarow, Y. (1925). The colorimetric determination of phosphorus. Journal of Biological Chemistry 66, 375-400.

GANDER, J. E. (1974). Fungal cell wall glycoproteins and peptidopolysaccharides. Annual Review of Microbiology 28, 103-119.

Gardell, S. (1953). Separation on Dowex 50 ionexchange resin of glucosamine and galactosamine, and their quantitative determination. Acta chemica scandinavica 7, 207-215.

Gorin, P. A. J. \& Spencer, J. F. T. (1968). Structural chemistry of fungal polysaccharides. Advances in Carbohydrate Chemistry 23, 367-417.

Hough, L., Jones, J. K. N. \& Wadman, W. H. (1950). Quantitative analysis of mixtures of sugars by the method of partition chromatography. V. Improved methods for the separation and detection of the sugars and their methylated derivatives on the paper chromatogram. Journal of the Chemical Society, 1702-1706.

Körw, E. \& GRönwall, A. (1952). Staining of protein-bound carbohydrates after electrophoresis of serum on filter paper. Scandinavian Journal of Clinical and Laboratory Investigation 4, 244-246.
Lloyd, K. O. \& Travassos, L. R. (1975). Immunochemical studies on L-rhamno-D-mannans of Sporothrix schenckii and related fungi by use of rabbit and human antisera. Carbohydrate $R e$ search 40, 89-97.

Lowry, O. H., Rosebrough, N. J., FARr, A. L. \& RANDALL, R. J. (1951). Protein measurement with the Folin phenol reagent. Journal of Biological Chemistry 193, 265-275.

MiYAZAKI, T. \& IRINo, T. (1970). Acidic polysaccharides from the cell wall of Absidia cylindrospora, Mucor mucedo and Rhizopus nigricans. Chemical and Pharmaceutical Bulletin, Tokyo 18, 1930-1931.

MiYAZAKI, T. \& IRINo, T. (1972). Studies on fungal polysaccharides. X. Extracellular heteroglycans of Absidia cylindrospora and Mucor mucedo. Chemical and Pharmaceutical Bulletin, Tokyo 20, 330-335.

MiYazaki, T., Yamada, H., Awaya, J. \& ŌMURA, S. (1976). Isolation and structure of an extracellular polysaccharide from Streptomyces sp. FERM-p1185. Journal of General Microbiology 95, 31-38.

Miyazaki, T., Suzuki, I., Yamada, H., Yadomae, T., Kumazawa, Y. \& Mizunoe, K. (1977). Studies on fungal polysaccharides. XXI. Serologically active substance(s) from Absidia cylindrospora. Kitasato Archives of Experimental Medicine (in the Press).

MORRIS, D. L. (1948). The quantitative determination of carbohydrates with Dreywood's anthrone reagent. Science 107, 254-255.

OUCHTERLONY, O. (1949). Antigen-antibody reactions in gels. Acta pathologica et microbiologica scandinavica 26, 507-515.

PARTRIDGe, S. M. (1948). Filter-paper partition chromatography of sugars. I. General description and application to the qualitative analysis of sugars in apple juice, egg white and fetal blood of sheep. Biochemical Journal 42, 238-250.

Trevelyan, W. E., Procter, D. P. \& Harrison, J. S. (1950). Detection of sugars on paper chromatograms. Nature, London 166, 444-445.

WESTPHAL, O. \& JAHN, K. (1965). Bacterial lipopolysaccharides. Extraction with phenol-water and further applications of the procedure. Methods in Carbohydrate Chemistry 5, 83-91. 